\title{
The Continuing Relevance of F.A. Hayek's Political Economy
}

\author{
Peter J. Boettke, Christopher J. Coyne and Peter T. Leeson ${ }^{*}$
}

\begin{abstract}
This paper explores the political economy of F.A. Hayek with emphasis on the continued relevance of his work for contemporary scholars. We focus on the theme of coordination throughout Hayek's research program. This general theme can be traced from Hayek's technical economics up through his later writings in political philosophy. After considering Hayek's major works in political and legal theory, we conclude by discussing the contemporary implications of Hayek's political economy. Specifically, we discuss eight areas where modern economists should pay close attention to the main lessons and themes in Hayek's writings.
\end{abstract}

\footnotetext{
* Peter J. Boettke (pboettke@gmu.edu) and Peter T. Leeson (pleeson@gmu.edu), Department of Economics, George Mason University, Fairfax, VA 22030; Christopher J. Coyne (chris.coyne@mail.wvu.edu), Department of Economics, West Virginia University, Morgantown WV 26506-6025. The authors would like to thank the Mercatus Center for their generous support of this research.
} 


\section{Introduction}

Friedrich A. von Hayek was arguably the most important classical liberal political economist of the twentieth century. Although trained as a technical economist, Hayek's body of work extended well beyond the discipline of economics. Indeed, the most productive reading of Hayek's body of work is as an interconnected research program of "political economy" that overlaps the disciplines of economics, politics and law (Boettke 1999). As Gordon notes, Hayek's "writings on these matters [the relation of economics to political philosophy] are unequalled in profundity, historical scholarship, and current relevance" (1981: 471). Our goal in this paper is to explore Hayek's political economy with emphasis on the continued relevance of this work for contemporary scholars.

In order to pursue this line of inquiry we first provide a discussion of the foundations of Hayek's political economy. It is our contention that the general theme of "coordination" can be traced from Hayek's technical economics up through his later writings in political philosophy (see O'Driscoll 1977). After exploring this foundation we discuss the historical context and main theme of Hayek's classic work, The Road to Serfdom. The Road to Serfdom is his perhaps Hayek's most well-known work. In addition to being a best seller in England and the United States, it has been translated into nearly twenty languages. Unauthorized copies of the book circulated throughout Eastern Europe before the collapse of the Berlin Wall. There can be little argument that Hayek's ideas have been influential throughout the world. Indeed, according to Hayek, the very reason he penned the book was "due to a peculiar and serious feature of the discussions of problems of future economic policy at the present time" (1944: xvii).

While The Road to Serfdom captures many critical elements of Hayek's political economy, it cannot be considered a complete explication of his political economy. Hayek's later 
works, such as The Constitution of Liberty (1960), and his three-volume Law, Legislation and Liberty $(1973,1976,1979)$ can be seen as developing and refining the arguments made in The Road to Serfdom. As such, after providing an overview of Hayek's classic work, in Section 4 we discuss some of the critical insights in Hayek's additional writings in political and legal theory.

We conclude the paper by discussing the contemporary implications of Hayek's political economy. We contend that Hayek's political economy is as relevant as ever and that modern economists should pay close attention to the main lessons and themes in Hayek's writings. The specific areas we consider include: ${ }^{1}$

1. New institutional economics

2. Institutional change

3. Development economics

4. Understanding the scope of spontaneous orders

5. Experimental economics

6. The cognitive turn in economic science

7. Understanding the costs of the growth of government

8. The classical liberal agenda

In order to demonstrate the continuing relevance of Hayek we discuss the impact his work has had in each of these areas, as well as the implications of this for future research.

\footnotetext{
${ }^{1}$ This is not an exhaustive list of all modern areas where Hayek's work is relevant. For example, Hayek's work is also important in the areas of complexity theory (see Rosser 1999, Caldwell 2004 and Koppl 2000 and 2006) and public choice (see Boettke and Lopez 2004) to name but two.
} 


\section{Coordination - The Foundation of Hayek's Political Economy}

At first blush, Hayek's writings appear to be disjointed, as they span a wide variety of disciplines. For instance, Hayek contributed to technical economics, political and legal theory and psychology, among other areas. ${ }^{2}$ However, we argue that there are several clear themes that run throughout these inter-disciplinary works:

1. The role of subjective knowledge in individual decision making.

2. The "compositive method" in which institutions must be explained as the result of "bottom up," individual action.

3. A clear recognition that economic phenomena do not exist independent of certain institutional, cultural, and legal structures.

Equally important is the fundamental question that Hayek was seeking to answer throughout his body of research. Beginning with his 1928 essay, Hayek established the central problem of economics as one of coordination. Hayek was preoccupied with the same question that puzzled Adam Smith some 150 years earlier: how does order emerge unintendedly from the actions of millions of economic actors? Carl Menger captured the importance of this issue when he asked: "How can it be that institutions which serve the common welfare and are extremely significant for its development come into being without a common will directed toward establishing them" (1883: 124)? Menger went on to note that, "this is the question of importance for our science..." (1883: 125).

Hayek's earliest writings in economics were focused on tracing out the implications of the coordination of economic activities through time. As his work matured, Hayek started to emphasize the institutions necessary for this dovetailing of plans among different individuals.

\footnotetext{
${ }^{2}$ For a discussion of the connections between Hayek's political theory and his work in economics, see Boettke 1999. Caldwell (2000, 2004: 270-279) and Horwitz (2000) discuss the connections between Hayek's economic theory and his work in cognitive psychology. Beaulier, Boettke and Coyne (2004) discuss Hayek's legal theory.
} 
His early economic writings on imputation, capital and interest theory, trade cycle theory, and monetary theory all had a "coordinationist" theme.

Hayek's focus on how individuals possessing dispersed knowledge of "time and place" learn and coordinate their activities, as well as the spontaneous orders that result from these interactions, underlies his entire research program. According to Hayek (1937: 50-51), the central question of all social science is:

how the spontaneous interaction of a number of people, each possessing only bits of knowledge, brings about a state of affairs in which prices correspond to costs, etc. and which could be brought about by deliberate direction only by somebody who possessed the combined knowledge of all those individuals.

For Hayek, economics is a science that studies coordination problems. It examines the dovetailing of plans by individual actors that must result so that complex social orders can emerge. Moreover, incentives must be aligned between actors. Individuals must come to know not only the best opportunities currently available for mutually-beneficial exchange, but must also continually discover new possibilities for mutual gain from exchange with others. Indeed Hayek's political economy stems directly from the realization that the institutional setting affects individual behavior and what is learned in an economic system. Keeping in mind these fundamental themes is critical in order to fully grasp his political economy.

\section{The Historical Context of The Road to Serfdom}

To better understand The Road to Serfdom, it is important to understand the historical context in which the book was written. The first edition of the book was published in Great Britain in March 1944. At the time, Great Britain and the United States were engaged in a World War with Nazi Germany. The Soviet Union was the main ally, while Nazi Germany was the major enemy. 
Many in Great Britain and the United States viewed the Soviet Union as a model of an ideal socialist society, which would result in widespread equality, and the removal of poverty. In stark contrast, Nazi Germany was viewed as a brutal dictatorship that allowed capitalist elites to maintain their entrenched positions.

Underlying the favorable view of the Soviet Union was a widespread acceptance of the socialist ideology by both intellectuals and the public. Indeed, the socialist critique of the liberal economic order had effectively shaped the ideological and intellectual terms of the debate by the beginning of the twentieth century. Most participants in the intellectual and political debate agreed that laissez-faire liberalism had failed to provide equality and humane social conditions. Instead, progressive legislation was demanded in order to correct for the failings of free competition. Sir William Harcourt captured this sentiment when he noted that "we are all Socialists now" (quoted in Trevelyan 1942: 510).

The Great Depression, which by popular interpretation of the time demonstrated that not only was capitalism unjust but that it was also unstable, contributed to the critique of laissezfaire liberalism. The collapse of the US and UK economies shook an entire generation's faith in the capitalist system. It was argued that if the capitalist system was to survive in the world of the 1930s, it had to be subject to democratic political forces of control. Continual government intervention was necessary to tame its operation and protect the populace from unscrupulous business and irresponsible speculation. Rational planning came to be viewed as not only a viable alternative to be debated, but also the only alternative to chaos.

In The Road to Serfdom, Hayek's aim was to demonstrate that Nazi Germany was not a result of inconsistencies in the capitalist system. Rather, the Nazi movement was a result of socialist ideology of the pre-World War I period that had been embraced by many intellectuals in 
both Great Britain and the United States. Hayek argued that this occurrence was not particular to Germany. Indeed, implementing socialist policies anywhere in the world could potentially lead to political tyranny.

It was Hayek's goal to explain how socialist ideas change the demands on democratic institutions and how these institutions are then transformed into tools of totalitarian rule. This transformation, Hayek argues, is due to the fact that democratic institutions are unable to meet these changing demands in a manner consistent with democratic principles. As Hayek summarizes the argument: "Is there a greater tragedy imaginable than that, in our endeavor to consciously to shape our future in accordance with high ideals, we should in fact unwittingly produce the very opposite of what we haven been striving for?" (1944: 5). Keeping in mind both the historical context in which Hayek wrote, as well as his main goals, we now turn to an overview of the main arguments in The Road to Serfdom.

\section{The Road to Serfdom: The Central Arguments}

The Road to Serfdom is broken into sixteen concise chapters that combine theory, intellectual history, and historical observation. The main focus of the book was to demonstrate the social consequences of ideas. Hayek envisions ideas as the motive force in history. Bad ideas are undesirable because they permit the rule of privileged interests over the common interest. Ideas provide a social infrastructure within which individuals pursue their own interests. In order to avoid political tyranny and economic servitude, these ideas must constrain the self-seeking behavior of individuals appropriately.

To understand the theoretical core of Hayek's argument, one has to look at the previous work of his teacher and mentor, Ludwig von Mises, regarding the feasibility of socialism as an 
economic system. In Socialism, (1922) Mises argued that "rational" economic calculation was impossible under a socialist system. Economic calculation is "rational" if decision-makers can efficiently allocate scarce capital resources among competing uses. Acting people must mentally process the alternatives available to them and to do so they must have some guide for comparing inputs and outputs. Mises' contribution was to establish that this decision-making ability (i.e., rational economic calculation) is dependent on the institutional context of private property. Mises reasoned as follows:

1. Without private production in the means of production, there will be no market for the means of production.

2. Without a market for a means of production, there will be no money prices established for the means of production.

3. Without money prices, reflecting the relative scarcity of capital goods, economic decision-makers will be unable to rationally calculate the alternative uses of capital goods.

In short, without private property in the means of production, rational economic calculation is not possible. Under institutional regimes that attempt to abolish private ownership in the means of production, decision makers will be in the dark with no guide as how to best allocate resources. In the world in which we live, economic decision-makers are confronted with many possible projects and economic calculation provides a guide for selecting the best project from an economic standpoint. In the absence of well-defined property rights in the means of production, decision-makers will have no guide for deciding which projects to pursue.

In his writings that preceded The Road to Serfdom, Hayek's contribution to Mises' argument was to elaborate the precise role that the price system played in providing information required for complex plan coordination. The Mises-Hayek argument demonstrated that the 
socialist system could not replicate what the private property and price system provided. No one mind or group of minds could possibly possess the knowledge necessary to coordinate a complex industrial economic system. In stark contrast, the private property and price system economizes on the information needed by economic actors to properly allocate resources.

Hayek proceeds in The Road to Serfdom under the assumption that this MiseseanHayekian theoretical argument has been established and accepted in the technical economic literature. Hayek's aim was not to establish that socialist planning could not achieve the efficiency that the capitalist system could. Rather, it was to demonstrate what would emerge from the failure of socialist planning to achieve its desired results. In other words, the MisesHayek technical economic calculation argument showed why socialism would fail; in The Road to Serfdom, Hayek showed what would result from that failure.

In the intellectual history provided in the first three chapters, Hayek's goal was to demonstrate that despite the Mises-Hayek critique of socialism, the socialist criticism of competition had effectively undermined the legitimacy of liberal institutions among the general public and especially among the intellectual elite. Liberalism, Hayek argued, imparted a "healthy suspicion" of any argument that demanded restrictions on market competition. With its critique of the competitive system, socialist theory had swept away the liberal constraints against special pleading and opened the door for interest groups demanding protection from competition under the flag of socialist planning (Hayek 1944: 40).

Hayek not only highlighted the economic issues with socialism, but also the political difficulties of planning. Indeed, Hayek's discussion of the delegitimation of the need for constraints on democratic government and the rule of law are one of the main arguments in The Road to Serfdom (1944: 56-87). In order for planning to be implemented, government officials 
cannot be constrained by formal rules but must be entrusted with discretionary power. Additionally, planning requires widespread agreement, and democracy is only capable of producing a certain level of agreement. Hayek argued:

That planning creates a situation in which it is necessary for us to agree on a much larger number of topics than we have been used to, and that in a planned system we cannot confine collective action to the tasks on which we can agree but are forced to produce agreement on everything in order that any action can be taken at all, is one of the features which contributes more than most to determining the character of a planned system (1944: 62).

What is the result of the need for widespread agreement?

...planning leads to dictatorship because dictatorship is the most effective instrument of coercion and the enforcement of ideals and, as such, essential if central planning on a large scale is to be possible. The clash between planning and democracy arises simply from the fact that the latter is an obstacle to the suppression of freedom which the direction of economic activity requires.

By its very nature, attempts at central planning will tend toward dictatorship because this is the only effective means of making the necessary decisions required by central planning.

Yet another key point Hayek makes in The Road to Serfdom is the liberal proposition that economic freedom and political freedom are linked. He argues that economic control does not control merely

a sector of human life which can be separated from the rest; it is the control of the means for all ends. And whoever has sole control of the means must also determine which ends are to be served, which values are to be rated higher and which lower - in short, what men should believe and strive for. Central planning means that the economic problem is to be solved by the community instead of by the individual; but this involves that it must be the community, or rather its representatives, who must decide the relative importance of the different needs (1944: 92).

Economic choices cannot be separated from the other choices made by individuals. As such, as planning increases, the freedoms and choices available to individual members of the populace will decrease. When the government decides what products are to be produced, there is little 
choice left to the individual citizen. The diverse preferences of the populace must be homogenized so that they conform to the central plan.

In addition to the highlighting the connection between economic and political freedom, Hayek also pointed out the organizational logic implied in the substitution of central decisionmaking for the private decisions of the citizenry in the marketplace. His analysis includes both an examination of the incentives faced by representatives creating the central plan, and the evolutionary process engendered by these institutions for the selection of leaders. Recall that Hayek assumed that the Mises-Hayek critique of socialism was widely accepted. Using this assumption as a starting point, he analyzed the organizational logic of central planning and what societal/institutional transformation would occur in response to the failure of the socialist system to achieve its stated ends.

Hayek took as a given that due to the inability of central planners to engage in rational economic calculation, they would ultimately fail to achieve their desired purpose. When faced with this failure, one potential option would be for government officials to reverse course and adopt liberal economic policies. Hayek argued that in a context where liberalism had been undermined by the socialist critique, government officials were unlikely to face sufficient incentives that would cause them to reverse course. As such, we should expect more interventions in the attempt to correct these past failures. This is the basis for the "slippery slope" argument whereby some initial intervention leads to an increasing number of future interventions in the attempt to remedy past failures.

Hayek's analysis of organizational planning under socialism is evident in Chapter 10, "Why the Worst Get on Top." Hayek warns the reader that since the economic knowledge necessary to plan the economy rationally will not be available to planners, these decision-makers 
will be forced to rely on the forms of information that are readily available. In the context of central planning, this comes in the form of incentives to exercise political power. Hayek's argument is that just as we should expect those with superior skills in any industry to rise to the top, we should also expect those who have superior skills in exercising political power and coercion to advance within the political apparatus of planning.

In pointing this out, Hayek was challenging the claim that experiments in real existing planning were tainted by "historical accident" and/or "bad" people and therefore could not be used to illustrate the difficulties associated with central planning. Hayek's counterargument was that it was not true that if only "good" people controlled the planning bureau, then the results would be harmonious with liberal democratic values. As Hayek wrote:

There are strong reasons for believing that what to us appears the worst features of the existing totalitarian systems are not accidental by-products but phenomena which totalitarianism is certain sooner or later to produce. Just as the democratic statesman who sets out to plan economic life will soon be confronted with the alternative of assuming dictorial powers or abandoning his plans, so the totalitarian dictator would soon have to choose between disregard of ordinary morals and failure. It is for this reason that the unscrupulous and uninhibited are likely to be more successful in a society tending toward totalitarianism (1944: 135).

In this context, success requires a skill set including the talent for "unscrupulous" and "uninhibited" moral behavior with respect to humanity. Totalitarianism is neither a consequence of "corruption" not "historical accident," but rather a logical consequence of the institutional incentive of the attempt to centrally plan an economy.

Throughout The Road to Serfdom, Hayek tells the tragic story of the consequences of central planning. It is not just that a band of thugs takes control of the coercive apparatus of the state and employs it to oppress the mass of citizens for their own benefit. Instead, the arbitrary employment of power is a consequence, and not a cause, of the desire to plan the economy 
scientifically. In order "to achieve their end, collectivists must create power - power over men wielded by other men - of a magnitude never before known, and...their success will depend on the extent to which they achieve such power" (1944: 144).

Even liberal socialists, as opposed to collectivists, in their desire to plan the economy, must establish institutions of discretionary planning and grant authority to the planners to exercise their political power in order to accomplish the task entrusted to them. The complexity of the task implied in planning an economic system would require that planners be granted almost unlimited discretion. As a result, we should expect that only those that possess superior talent in exercising discretionary power would survive.

\section{Hayek on the State, Individual, Economic Freedom, and the Law}

Hayek's interest in political and social theory, starting with The Road to Serfdom, continued in his later writings, specifically The Constitution of Liberty (1960) and the three-volume Law, Legislation and Liberty $(1973,1976,1979)$. It is not Hayek's purpose in The Road to Serfdom to explore what the role of the state should be, but rather to trace the consequences of ideas and specifically the adoption of socialist ideas and practices. In his later writings, Hayek focused more directly on the role of the state in the context of individual and economic freedom, as well as the legal system. In this section we consider some of the main ideas in these later writings. As will become clear to the reader, much of Hayek's analysis regarding the role of the state, the legal system and political and economic freedom are outgrowths of the arguments made in The Road to Serfdom and the themes found in his earlier economic writings. According to Hayek, "The possibility of men living together in peace and to their mutual advantage without having to agree on common concrete aims and bound only by abstract rules of conduct was perhaps the 
greatest discovery mankind ever made" (1976: 136). Starting with The Road to Serfdom, Hayek's writings should be read as an analysis of the moral and political significance of this discovery as well an examination of the threats to its sustainability (Gordon 1981: 472).

As discussed at the outset, an emphasis on dispersed, local knowledge of time and place, understanding how individuals coordinated their activities and the spontaneous orders emerging from these interactions are at the center of Hayek's research program. In this regard, Hayek sought to understand how individuals can best learn and act on this dispersed knowledge. He concluded that a respect for private property, a well-functioning rule of law, and a stable monetary order were crucial for individual experimentation, learning, and widespread coordination.

In the Constitution of Liberty (1960), Hayek argues that these institutions provide a predictable environment within which people can orient their behavior (1960: 148-161). As Hayek writes:

The significance for the individual of the knowledge that certain rules will be applied is that, in consequence, the different objects and forms of action acquire for him new properties. He knows of man-made cause-and-effect relations which he make use of for whatever purpose he wishes. The effects of these man-made laws on his actions are of precisely the same kind as of the laws of nature: his knowledge of either enables him to foresee what will be the consequences of his actions, and it helps him to make plans with confidence" (1960: 153).

Rules and laws are designed in the absence of perfect foresight. In other words, those developing rules and laws cannot know the particular case where they will be applicable. As such, general rules, which are predictable and known by all, allow unforeseeable situations to be dealt with in the most effective manner.

Hayek recognized the need for general rules that allowed individuals with dispersed knowledge to learn and, at the same time, limited the amount of harm that could be done by any 
one individual. He realized that each individual is imperfect and as such we must develop the rules of the game so that the best of all possible worlds will not be the enemy of the "good" society. Hayek pointed this out, as well as the connection of his research program with that of the Scottish Enlightenment program, when he wrote:

[T] he main point about which there can be little doubt is that [Adam] Smith's chief concern was not so much with what man might occasionally achieve when he was at his best but that he should have as little opportunity as possible to do harm when he was at his worst. It would scarcely be too much to claim that the main merit of the individualism which he and his contemporaries advocated is that it is a system under which bad men can do least harm. It is a social system which does not depend for its functioning on our finding good men for running it, or on all men becoming better than they now are, but which makes use of men in all their given variety and complexity, sometimes good and sometimes bad, sometimes intelligent and more often stupid (1948: 11-12).

In this sense, Hayek's political economy can be viewed as "robust" in that his aim is to develop a system that will sustain and remain strong even in the presence of imperfect individuals. Hume captured the issue of robustness when he noted:

Political writers have established it as a maxim, that, in contriving any system of government, and fixing the several checks and controuls of the constitution, every man ought to be supposed a knave, and to have no other end, in all his actions, than private interest. By this interest we must govern him, and, by means of it, make him, notwithstanding his insatiable avarice and ambition, co-operate to public good. Without this, say they, we shall in vain boast of the advantages of any constitution, and shall find, in the end, that we have no security for our liberties or possessions, except the good-will of our rulers; that is, we shall have no security at all (1742: 40-42).

Hayek continued the development of this political economy project in Law, Legislation and Liberty $(1973,1976,1979)$. The main theme of this trilogy is that rules must be general, non-arbitrary, and equally applied to all individuals. This pure "Rule of Law," as Hayek calls it, must serve as the backdrop for imperfect agents. Given a predictable legal code, individuals can learn and adapt their behavior in order to coordinate their activities with those of others. 
Consistent with the generality principle mentioned above, Hayek claims that in a free society only the general welfare can be pursued and not the particular aims of any individual within society. According to Hayek, many contemporary notions of social justice are focused on the particular case of individuals within the general order. But, in Hayek's system, justice can only be maintained at the level of the general legal framework and rules of the game. Specific actions designed to remedy certain instances of "injustice" will fail to effectively remedy the situation and will undermine the general system.

To understand Hayek's argument, it must first be realized that political decisions are never about particular distributions of resources. Instead, political decisions are decisions that affect the rules of the economic game. These rules create a set of expectations and a resulting pattern of exchange, production and distribution. The "mirage of social justice," is the belief that specific distributional outcomes can be picked independent of the very process through which exchange and production takes place. The rules of just conduct serve to govern the means by which various purposes and plans are pursued. As such, these rules serve to reconcile the actions pursued by disparate individuals within the general order governed by these rules. In contrast, a command serves a particular purpose and as such is in direct conflict with rules of just conduct. Put simply, discriminatory laws undermine the rules of just conduct and the framework of a just society.

After describing and defending the "rule of law" in Volumes 1 and 2 of Law, Legislation and Liberty, Hayek makes the case for political constraints in the third and final volume (1979). Recognizing the role interest groups play in democratic political systems, Hayek argued that the problem with limited democracy is that it becomes "the playball of all separate interests it has to satisfy to secure majority support" (1979: 99). As a result, the government becomes unable to 
accomplish the tasks required for good governance. Thus, constraints are necessary to avoid the devolution into arbitrary, unconstrained, interest-group government.

At this point, the reader can hopefully see the interconnectedness between Hayek's various strands of work. The underlying inquiry that drove all of Hayek's research was: how do individuals learn to coordinate their economic activities with those of others under varying institutional arrangements? In his earliest work, he focused on this question in the context of economic theory - capital structure, interest rates and monetary theory, etc. Starting with The Road to Serfdom, his concern with these issues became more focused on the implications of various political systems. This focus on political, social and legal theory continued throughout the rest of his career.

\section{Conclusion - Hayek's Relevance Today}

F.A. Hayek's political economic insights are as relevant today as when they were first written. A number of areas in the contemporary economics landscape reflect the continuing importance Hayek's ideas. These areas include:

\section{New Institutional Economics}

New institutional economics (NIE) focuses on the study of institutions and the interplay between institutions and other organizational arrangements (Menard and Shirley 2005: 1). Further, NIE assumes that actors have imperfect information and face constant uncertainty. The emphasis on institutions, as well as the abandonment of standard neoclassical assumptions of perfect information and rationality can be found throughout Hayek's work. In his review of the state of NIE, Oliver Williamson (2000) highlights Hayek as a critical precursor to NIE. As such, the NIE research program should be seen as building on Hayek's political economy. 


\section{Institutional change}

Hayek's influence is also evident in the effort to understand institutional quality and institutional change (Boettke et al. 2005). For example, Hayek's influence can be seen in the work of Olson (2000) and Djankov et al. (2003) on institutional quality and the politics of predation. Hayek's focus on the "bottom-up" emergence of institutions versus the "top-down" imposition of institutions is relevant given ongoing efforts to "export" liberal institutions to countries where they do not currently exist (see, for instance, Coyne 2007). In general, Hayek forces us to realize that different institutional settings create different economic, social and political outcomes. Understanding the various outcomes of different institutional settings is an empirical question.

In the realm of public policy, arguments about institutions and institutional capacity are more prevalent today than ever before. The idea that we need simple rules for a complex world is no longer considered unthinkable and is much more common than the idea that because of complexity we need detailed interventions. ${ }^{3}$ It is now a conventional wisdom that rules outperform discretion in the realm of public policy. Policy analysis has moved to the level of the rules of the game that create the institutional environment within which economic activity takes place. This is most evident in the public policy discussion surrounding development economics and the emphasis on creating an institutional environment that cultivates an entrepreneurial environment where individuals are enabled to realize the mutual gains from trade. Cooperation is encouraged, and conflict minimized due to the institutional environment that is adopted in any given society (see, for instance, Ostrom et al. 2002).

\footnotetext{
${ }^{3}$ For example, The 2004 Nobel Prize to Kydland and Prescott for, in part, their work on rules versus discretion can be seen as consistent with this basic Hayekian point.
} 


\section{Development economics}

Many underdeveloped countries suffer from the very problems Hayek was analyzing in his writings. In many of these countries corruption is rampant. Property is coercively redistributed rather than protected. A stable rule of law is absent as the legal system is unpredictable and constantly changing. Hayek's political economy offers insight into these outcomes. For example, Hayek's work has proven to be extremely prescient and relevant for current debates in growth theory as illustrated by the work of Mahoney (2001) and Glaeser and Shleifer (2002).

The recognition of the importance of entrepreneurship to understanding growth continues to spur economists to find ways to incorporate the elusive concept of entrepreneurship into the understanding of the competitive market process (see Baumol 2002). Some of this research is amenable to standard empirical work, but there has also been a growing recognition that work that emphasizes institutions and economic change must eschew cross-country data analysis and engage in detailed micro-data analysis of specific context. This can be accomplished through an analytic narrative approach (see Bates et al. 1998), ethnographic analysis of underground economies (e.g., de Soto 1989), or micro-data surveys (e.g., Frye 2000). Empirical economics is going through a transformation just as drastic as theoretical economics and it is doing this in line with Hayek's focus on disaggregation and in a manner that is consistent with the subjectivist notion of developing a political economy of everyday life that respects the meaning that individuals construct and place on their activities and the activities of others.

\section{Understanding the scope of spontaneous orders}

A growing research explores the extent to which spontaneous orders can evolve and operate in the absence of the state (see, for instance, Leeson 2007a, 2007b; 2007c; Benson 1989; Anderson 
and Hill 2004). An important aspect of Hayek's work is the emergence of spontaneous orders that facilitate cooperation versus the need for the state to formally legislate rules to foster cooperation. The central question becomes the extent and robustness of governance mechanisms, their ability to handle problems of social diversity, large populations, and capacity to handle violence.

\section{Experimental economics}

Vernon Smith (2005) has noted that his work in experimental economics was originally inspired by Austrian economics, and specifically the work of Hayek. Indeed, Smith sees his research as contributing to key questions asked by Hayek long ago: how do individuals utilize human knowledge that is dispersed and can never be possessed by a single individual? Under what conditions will individuals partake in mutually beneficial exchanges without any influence from a central planner? Moreover, Smith emphasizes that laboratory experiments allow for the observance of the emergence of spontaneous orders in the form of rules governing the market and market exchanges. In this regard, the field of experimental economics should be seen as a direct descendent of Hayek's political economy.

\section{The cognitive turn in economic science}

In the realm of economic science, Hayek's influence can be seen in the cognitive direction of research (see Koppl 2006) that has been taken by Kuran (1995) and North (2004). Several scholars, including Gilad (1982) and Harper $(1996,1998)$ have incorporated the psychological concept of "locus of control" into the theory of entrepreneurship. ${ }^{4}$ Finally, the Hayekian view of cognition can be seen in the works of complexity theorists including Holland (1992) and by

\footnotetext{
${ }^{4}$ Volume 7 of Advances in Austrian Economics addresses "Evolutionary Psychology and Economic Theory."
} 
Kauffman (1993). ${ }^{5}$ Hayek's The Sensory Order (1952) will continue to play a role in the development of this sub-field (see Caldwell 2004: 270-279).

\section{Understanding the costs of the growth of government}

Even in developed countries such as the United States, one observes a steady increase in the level of government intervention over time. Often, special interests are protected through regulation, and protective measures such as tariffs. There have been frequent calls for nationalized healthcare despite the fact that the Medicare system is bankrupt. One also observes a call for more government involvement in forced savings through interventions in the Social Security system. Government spending has increased dramatically year over year.

While the type of central planning employed in the Soviet Union is no longer with us, governments around the world - in both developed and underdeveloped nations - continually implement programs designed to increase the scope of the state. As Hayek demonstrated, following such a course of action runs counter to economic development as well as political and individual freedom. Some scholars, such as Higgs (1987), have empirically explored how the onset of crisis leads to permanent growth in the size government. As Hayek noted in The Road to Serfdom, oftentimes efforts to utilize government to combat tyranny elsewhere actually result in the unintended consequence of movements toward tyranny at home.

\section{The classical liberal agenda}

In the realm of ideological commitment, a new generation of liberal scholars have emerged who have taken up Hayek's ideas and run farther with them than even Hayek dared to imagine.

\footnotetext{
${ }^{5}$ See also Butos and McQuade 2005. Butos 2003 explores Hayek's cognitive theory and the implications for the Austrian notion of rationality.
} 
Kukathus (2003), for example, argues that the toleration of religious and ethnic minorities provided by liberal institutions must be pursued to its logical conclusion even in the world that we live in today. Also, recent work on decentralized governance and law by Benson (1990) has developed Hayek's distinction between law and legislation in a consistent manner. Finally, the work by scholars such as Weingast (1995) on market preserving federalism is another example where the argument for decentralized governance and fiscal federalism that Hayek made is inspiring new theoretical presentation and empirical investigation.

We have argued that F.A. Hayek's political economy is as relevant today as when it was first written. Modern scholars of political economy would do well to go back to Hayek for untapped ideas and for a deeper understanding of the issues relevant to this area of study. Much of the current work in political economy can be traced back to Hayek, even if his influence not explicitly recognized by the authors (see for instance, Acemoglu and Johnson 2005, Acemoglu, Robinson and Johnson 2001, 2001 and Glaeser and Shleifer 2002). These writings also demonstrate how Hayek's political economy can generate fruitful empirical analysis. Hayek's writings consisted of many empirical claims and these studies have contributed to the testing and analysis of some of Hayek's hypotheses. This growing empirical literature demonstrates the continued significance of Hayek's political economy. It is our hope that modern scholars will recognize the lasting importance of Hayek's research program. 


\section{References}

Acemoglu, Daron and Simon Johnson (2005). "Unbundling Institutions." Journal of Political Economy, 115: 949-995.

Acemoglu, Daron, Simon Johnson, and James Robinson (2001). "The Colonial Origins of Comparative Development: An Empirical Investigation." American Economic Review, 91: 1369-1401.

Acemoglu, Daron, Simon Johnson, and James Robinson (2002). "Reversal of Fortunes: Geography and Institutions in the Making of the Modern World Income Distribution." Quarterly Journal of Economics, 117: 1231-1294.

Anderson, Terry and P.J. Hill. 2004. The Not So Wild, Wild West. Stanford: Stanford University Press.

Bates, Robert H. Avner Greif, Margaret Levi, Jean-Laurent Rosenthal and Barry R. Weingast. 1998. Analytic Narratives. Princeton: Princeton University Press.

Baumol, William. 2002. The Free-Market Innovation Machine. Princeton: Princeton University Press.

Beaulier, Scott, Peter J. Boettke and Christopher J. Coyne. 2004. "Knowledge, Economics and Coordination: Understanding Hayek's Legal Theory," NYU Journal of Law \& Liberty, 1: $209-224$

Benson, Bruce. 1989. "The Spontaneous Evolution of Commercial Law," Southern Economic Journal, 55(3): 644-661.

. 1990. The Enterprise of Law. San Francisco, CA: Pacific Research Institute for Public Policy.

Boettke, Peter J. 1999. "Which enlightenment, whose liberalism? Hayek's research program for understanding the liberal society." In, The Legacy of Friedrich von Hayek, Volume 1, Peter J. Boettke ed. Cheltenham: United Kingdom.

Boettke, Peter J., Christopher J. Coyne, Peter T. Leeson and Frederic Sautet. 2005. "The New Comparative Political Economy,” The Review of Austrian Economics, 18(3/4): 281-304.

Boettke, Peter J. and Edward J. Lopez. 2004. "Austrian Economics and Public Choice," Review of Austrian Economics, 15(2/3): 111-19.

Butos, William N. 2003. "Knowledge Questions: Hayek, Keynes, and Beyond," Review of Austrian Economics, 16(4): pp. 291-307.

Butos, William and Thomas J. McQuade. 2005. “The Sensory Order and Other Adaptive 
Classifying Systems," Journal of Bioeconomics, 7(3): 335-58.

Caldwell, Bruce. 2000. “The Emergence of Hayek's Ideas on Cultural Evolution," The Review of Austrian Economics. 13(5): 5-22. . 2004. Hayek's Challenge: An Intellectual Biography of F.A. Hayek. Chicago: The University of Chicago Press.

Coyne, Christopher J. 2007. After War: The Political Economy of Exporting Democracy. California: Stanford University Press.

Djankov, Simeon, Edward Glaeser, Rafael La Porta, Florencio Lopez-de-Silanes, and Andrei Shleifer. 2003. "The New Comparative Economics." Journal of Comparative Economics, 31(4): 595-619.

De Soto, Hernando. 1989. The Other Path. New York: Harper Collins.

Frye, Timothy. 2000. Brokers and Bureaucrats. Ann Arbor, MI: University of Michigan Press.

Gilad, B. 1982. "On encouraging entrepreneurship: An interdisciplinary approach," Journal of Behavioral Economics. 11(1): 132-163.

Glaeser, Edward L and Andrei Shleifer. 2002. "Legal Origins," Quarterly Journal of Economics 117: 1193-1230.

Gordon, Scott. 1981. "The political economy of F.A. Hayek," Canadian Journal of Economics. XIX(3): 471-487.

Harper, David. 1996. Enterpreneurship and the market process: An inquiry into the growth of knowledge. London: Routledge.

Harper, David. 1998. "Institutional conditions for entrepreneurship," Advances in Austrian Economics, 5: 241-275.

Hayek, Friedrich A. 1928. "Intertemporal price equilibrium and movements in the value of money." In Hayek 1984.

. 1937. "Economics and knowledge." In Hayek 1948.

. 1944. The Road to Serfdom. Chicago: University of Chicago Press.

. 1948. Individualism and Economic Order. Chicago: University of Chicago Press.

. 1952. The Sensory Order. Chicago: Chicago University Press.

. [1960] 1978. The Constitution of Liberty. Chicago: University of Chicago Press. 
1973. Law, Legislation and Liberty: Rules and Order, Volume 1. Chicago: University of Chicago Press.

. 1976. Law, Legislation and Liberty: The Mirage of Social Justice, Volume 2. Chicago: University of Chicago Press.

1979. Law, Legislation and Liberty: The Political Order of a Free People, Volume 3. Chicago: University of Chicago Press. 1984. Money, Capital \& Fluctuations. Chicago: University of Chicago Press.

Higgs, Robert. 1987. Crisis and Leviathan: Critical Episodes in the Growth of American Government. New York: Oxford University Press.

Holland, John H. 1992. Adaptation in Natural and Artificial Systems: An Introductory Analysis with Applications to Biology, Control, and Artificial Intelligence, Cambridge, Mass: The MIT Press.

Horwitz, Steven. 2000. "From The Sensory Order to the Liberal Order: Hayek's Non-rationalist Liberalism," The Review of Austrian Economics 13: 23-40.

Hume, David. [1742] (1985). Essays: Moral, Political, and Literary. Eugene F. Miller ed. Indianapolis: Liberty Fund, Inc.

Kauffman, Stuart A. 1993. The Origins of Order: Self-Organization and Selection in Evolution, New York and Oxford: Oxford University Press.

Kopp1, Roger. 2000. "Teaching Complexity: An Austrian Approach," in Colander, David, ed. The Complexity Vision and the Teaching of Economics, Cheltenham, UK Edward Elgar.

. 2006. "Austrian economics at the cutting edge." The Review of Austrian Economics, 19(4): 231-241.

Kukathas, Chandran. 2003. The Liberal Archipelago: A Theory of Diversity and Freedom. New York: Oxford University Press.

Kuran, Timur. 1995 Private Truths, Public Lies. Cambridge, MA: Harvard University Press.

Leeson, Peter T. 2007a. “Trading with Bandits," Journal of Law and Economics, 50(2): 303-321.

Leeson, Peter T. 2007b. “Social-Distance and Self-enforcing Exchange," Journal of Legal Studies, forthcoming.

Leeson, Peter T. 2007c. “Efficient Anarchy,” Public Choice, 130(1-2): 41-53. 
Mahoney, Paul G. 2001. "The Common Law and Economic Growth: Hayek Might Be Right," Journal of Legal Studies. 30(2): 503-525.

Ménard, Claude and Mary M. Shirley. 2005. “Introduction,” In., Handbook of New Institutional Economics, Ménard, Claude and Mary M. Shirley (eds.) New York: Springer, pp. 1-20.

Menger, Carl. [1883] 1996. Investigations Into The Methods of The Social Sciences. Grove City, PA: The Libertarian Press, Inc.

Mises, Ludwig von [1922] 1981. Socialism: An Economic and Sociological Critique. Indianapolis: Liberty Fund.

North, Douglass. 2004. Understanding the Process of Economic Change. Princeton: Princeton University Press.

O'Driscoll, Gerald P. 1977. Economics as a Coordination Problem: The Contributions of Friedrich A. Hayek. Kansas City: Sheed Andrews and McNeel, Inc.

Olson, Mancur. 2000. Power and Prosperity. New York: Basic Books.

Ostrom, Elinor, Clark Gibson, Sujai Shivakumar, and Krister Andersson. 2002. Aid, Incentives and Sustainability. Stockholm, SW: SIDA.

Rosser, Barkley. 1999. "On the Complexities of Complex Economic Dynamics," Journal of Economic Perspectives, 13(4): 169-192.

Smith, Vernon. 2005. "Hayek and Experimental Economics," The Review of Austrian Economics, 18(2): 135-144.

Trevelyan, George M. 1942. Shortened History of England. London: Longmans.

Weingast, Barry. 1995. "The Economic Role of Political Institutions," Journal of Law, Economics and Organization, 11(1): 1-31.

Williamson, Oliver. 2000. "The New Institutional Economics: Taking Stock and Looking Ahead," Journal of Economic Literature. 38(3): 595-613. 